\title{
Functional Response of Phytoseiulus persimilis Athias-Henriot to the Two-Spotted Spider Mite Different Stages (Acari: Tetranychidae)
}

\author{
M. A. Osman ${ }^{*}$ and A. A. Tawfik ${ }^{*}$ \\ "Agricultural Zoology Dept., Fac. of Agric., Mansoura Univ., Mansoura, Egypt mesoma20@mans.edu.eg \\ "* Plant Protection Research Institute, Agricultural Research Center, Dokki, Cairo, Egypt.
}

(Received: July 25, 2010)

\begin{abstract}
The objective of this study was to determine the functional response of the predator Phytoseiulus persimilis Athias-Henriot fed on Tetranychus urticae koch larvae, nymphs and adults at different densities. A logistic regression of the proportion of prey consumed as a function of initial prey density was conducted to identify functional response types, and used nonlinear least-squares regression and the random predator equation to estimate attack rates and handling times. Overall, adult females $P$. persimilis exhibited a type 2 functional response to $T$. urticae. Whereas, attack rate $(a)$ and handling time $\left(T_{12}\right)$ of $P$. persimilis recorded $0.1722,0.5034$ and 0.4776 and $1.4699,2.1133$ and 3.051 when offering larvae, nymphs and adults of T. urticae respectively.
\end{abstract}

Key Words: Functional response, Phytoseiulus persimilis, Tetranychus urticae, Attack rate, Handling time.

\section{INTRODUCTION}

In Egypt, Rasmy and El-Laithy (1988) introduced the exotic predatory mite Phytoseiulus persimilis Athias-Henriot for biological control of Tetranychus urticae koch in green houses. Later on, many researchers have studied the feasibility of using this predator in biological control of T. urticae in greenhouse and open fields (El-Laithy, 1992; El-saiedy, 1999; El-saiedy, 2003; Osman, 2005 and Mahgoub, 2006) but the functional response of $P$. persimilis to different immatures stages of T. urticae has not been studied yet.

Functional response is defined as the relationship between the number of prey consumed per predator and prey density (Solomon, 1949 and Holling, $1959 \mathrm{a}, \mathrm{b})$. It plays a pivotal role in the understanding of prey-predator interactions and their ecological and evolutionary consequences (Tully et al., 2005). Holling (1959a) identified three basic types of functional responses in general. The Type I response is characterized by a linear rise with a constant attack rate over all prey densities until satiation is reached. In the Type II response the attack rate decreases as prey density increases. Type III is represented by a sigmoid curve where the attack rate increases with increasing prey density, then decreases towards satiation. Type II and III responses have generated the most ecological interest and most studies are confined to these lwo response ty pes (Juliano, 2001). In terms of biological control. predators and parasitoids which exhibit the type III functional response, by showing positive density-dependent prey consumption. are ustally regarded as efficient biological control agents (Perve\% and
Omkar, 2005). Nevertheless, there are some examples of natural enemies with the type II functional response model which have been successfully used as biological control agents (Luck, 1984; Hughes et al., 1992; Femandez-Arhex and Corley, 2003 and Mandour, et al., 2006). Most arthropod predators possess type II response (Holling, 1961; Royama, 197I; Oaten \& Murdoch, 1975 and Hassell, 1978). Holling (1961) divided the functional response into several basic and subsidiary components. The attack rate (a) can be considered to be a function of: (1) the reaction distance of the predator, i.e., the maximum distance at which the predator will react by attacking prey; (2) the speed movement of predator and prey; and (3) the proportion of attacks that are successful. The handling time $\left(T_{h}\right)$ can be considered to be a function of: (1) the time spent pursuing an individual prey; (2) the time spent investigating and probing each prey; and (3) the time spent drilling each prey. The time as prey and predator exposure (T) can be considered to be a function of: (1) time in non-ovipositing activities; and (2) time in ovipositing-related activities (i.e., $T_{h}$ ). The functional response of phytoseiid mites to the density of tetranychid mites has been investigated by many authors (Chant, 1961: Holling, 1974; Laing and Osborn, 1974: Santos. 1975; Everson, 1979: Sabelis, 1985: Badii et al. 1999: Cuellar et al., 2001 and van Rijn et al.. 2005).

The objective of this study was to investigate the functional response of $P$. persimilis when preying on $T$. urticue to improve our understanding of prey-predator interaction and get a better strategy for the biological control of $T$. unticae using $P$. persimilis. 


\section{MATERIALS AND METHODS}

\section{Mite culture}

Culture of the predatory mite $P$. persimilis was obtained from National Research Center, Cairo, Egypt.

Copulated adult females of $P$. persimilis were left to lay eggs on leaf discs of castor plants Ricinus communis placed on a moist cotton pad in Petri-disches, $15 \mathrm{~cm}$ in diameter at $25 \pm 1{ }^{\circ} \mathrm{C}$ and $70 \pm 5 \%$ RH. and provided with the spider mites T. urticae as prey.

\section{Functional response}

Newly emerged adult females of $P$. persimilis were singly transferred to modified Huffaker cells and starved for 24hr (Sabelis, 1981; Overmeer, 1985). These closed cells were prepared with a piece of Plexiglas ( $8 \cdot 4 \mathrm{~cm}$ and $5 \mathrm{~mm}$ of thickness) with a circular hole of diameter $1.5 \mathrm{~cm}$ in the middle of the plate. A second Plexiglas plate of the same size forms the base of the cell. On this second plate, a moistened filter paper was laid on which a piece of leaf of castor plants was placed upside down. The piece of Plexiglas with the hole was then placed on the leaf. A transparent coverslip closed the cell and all the pieces were held together with rubber bands. Therefore, each stage of T. urticae larva, nymph and adult was introduced as prey into modified Huffaker cells at densities of $4,8,12,16,20,24,28,32,36$ and 40 . Each density treatment was replicated ten times. After $24 \mathrm{hr}$, numbers of dead and living T. urticae were recorded.

\section{Data analysis}

The experimental data was analysed following Juliano (2001). The functional response type was determined by a logistic regression of the proportion of prey consumed as a function of initial prey number. Then, the data were fitted by an appropriate equation by the nonlinear least-squares regression. The polynomial equation was used to fit the data on the proportion of prey consumed:

$$
\begin{aligned}
& \mathrm{N}_{\mathrm{a}} \\
& \mathrm{N}_{0}
\end{aligned}=\frac{\exp \left(\mathrm{P}_{0}+\mathrm{P}_{1} \mathrm{~N}_{0}+\mathrm{P}_{2} \mathrm{~N}_{0}{ }^{2}+\mathrm{P}_{3} \mathrm{~N}_{0}{ }^{3}\right)}{1+\exp \left(\mathrm{P}_{0}+\mathrm{P}_{1} \mathrm{~N}_{0}+\mathrm{P}_{2} \mathrm{~N}_{0}{ }^{2}+\mathrm{P}_{3} \mathrm{~N}_{0}{ }^{3}\right)}-\cdots(\mathbf{1})
$$

Where, $N_{a}$ is the number of prey eaten, $N_{0}$ is the initial number of prey, and $P_{0}, P_{1}, P_{2}$ and $P_{3}$ are the intercept, linear, quadratic and cubic coefficients respectively. These parameters can be estimated using the CATMOD procedure in SAS (Juliano 2001). The logistic regression was used to obtain the maximum likelihood estimates of parameters $P_{0}$ to $\mathrm{P}_{3}$. The functional response type was determined by the sign of the linear coefficient from equ. (1) and the significance of the parameters from the logistic model was evaluated by $\log$ likelihood tests. If $\mathrm{P} 1<0$, it describes a type 2 functional response. If $\mathrm{P} 1>0$ and $\mathrm{P} 2<0$, it presents a type 3 functional response (Juliano 2001) Because logistic regression analysis indicated that the present data fit the type 2 response, further analysis was restricted to the type 2 response.

In a second step, a nonlinear least squares regression of number of prey eaten vs. number offered was used to estimate and compare parameters of functional responses following the NLIN procedure in SAS. Functional response data were fitted to the random predator equation equ. (2) Royama (1971) and Rogers (1972) to describe the type 2 functional response:

$N a=N\left\{1-\exp \left[-a \mathrm{~T} /\left(1+\mathrm{a} T_{\mathrm{h}} N\right)\right]\right\}$

where $\mathrm{Na}$ number of prey attacked per predator during experimental period $\mathrm{T}(24 \mathrm{~h}) ; N$ the initial prey density; $a$ is the attack rate, $T_{h}$ is the handling time of prey by the predator and $\mathrm{T}$ is the total time during which prey and predator are exposed to each other. The parameters $a$ (the rate of successful attack) and $T_{h}$ (the time required to handle a prey item) were calculated using least-squares non-linear regression. Whereas, $T_{h}$ values were used to calculate maximum attack rate as $T / T_{h}$ (Hassell, 1978), this represent the maximal number of prey individuals that could be consumed by $P$. persimilis during $24 \mathrm{hr}$.

\section{RESULTS AND DISCUSSION}

The average number of $T$. urticae devoured by $P$. persimilis varied with prey stage, but increased with prey density during a $24 \mathrm{hr}$ period. Prey consumption by $P$. persimilis increased from 4 to 20 , 4 to 28 and 4 to 28 individual with increase in density of larvae, nymphs and adults of $T$. urticae, respectively. On the other hand, the proportion of killed preys by $P$. persimilis decreased from 1 to $0.03,1$ to 0.13 and 1 to 0.21 with increase in density of adults, nymphs and larvae of $T$. urticae respectively. (Fig. $1 \mathrm{~A} \& \mathrm{~B}$ ). Decreasing in proportion of prey consume with increasing prey density is known for arthropod predator (Holling, 1961).

Data presented in table (1) showed that the outcome of the logistic regression of adult female $P$. persimilis to larvae, nymphs and adults of T. urticae reflected a type II functional response, in all cases the sign of the linear term was negative (Table 1). 

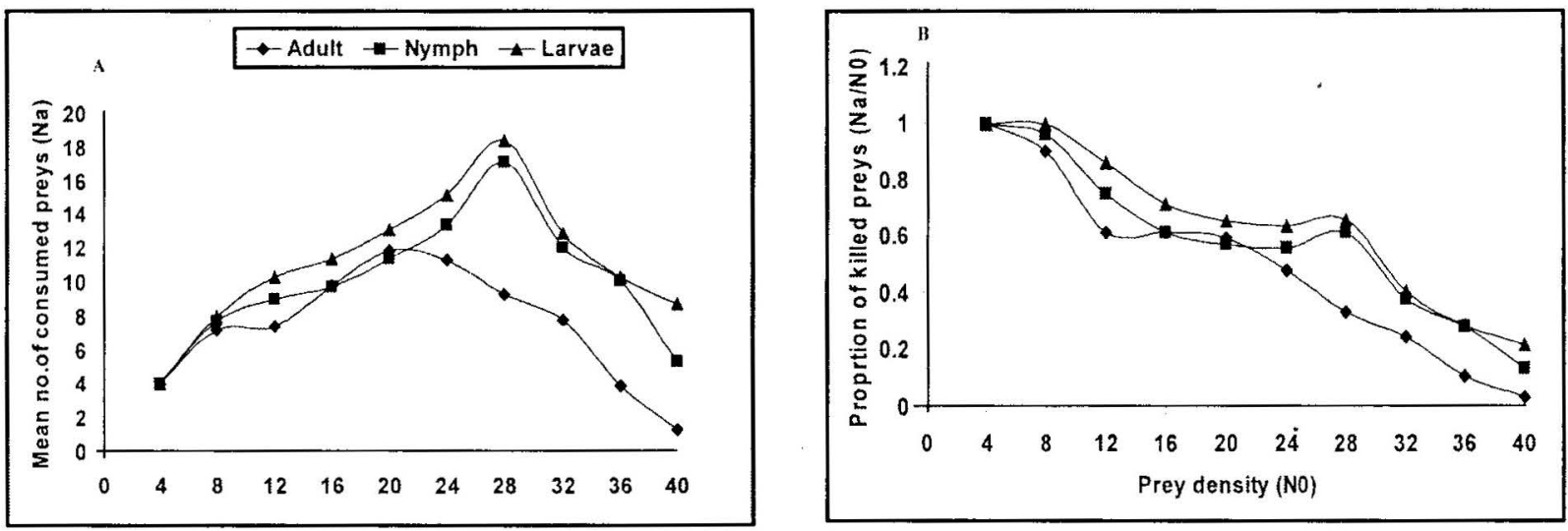

Fig. (1 A \& B): Observed functional response of Phytoseiulus persimilis females to densities of larvae, nympls and adults of Tetranychus urticae.

Table (1): Results of logistic regression analyses, indicating estimates and standard errors of linear, quadratic and cubic coefficient for the proportion of prey eaten by P.persimilis against initial preys number offered at $25^{\circ} \mathrm{C}$.

\begin{tabular}{|c|c|c|c|c|}
\hline age & Coefficient Estimate & S. E & $\chi^{2}$ & $\mathrm{P}$ \\
\hline \multirow{4}{*}{ تِ } & Intercept $\mathrm{P}_{0} \quad 11.7790$ & 1.4634 & 64.79 & $<0.0001$ \\
\hline & Linear $P_{1}$ & 0.1793 & 53.03 & $<0.0001$ \\
\hline & $\begin{array}{ll}\text { Quadratic } P_{2} & 0.0479\end{array}$ & 0.00694 & 47.52 & $<0.0001$ \\
\hline & -0.00058 & 0.000085 & 45.81 & $<0.0001$ \\
\hline \multirow{4}{*}{ 空 } & Intercept $\mathrm{P}_{0}$ & 1.0659 & 59.31 & $<0.0001$ \\
\hline & Linear $P_{1}$ & 0.1402 & 48.89 & $<0.0001$ \\
\hline & Quadratic $P_{2} \quad 0.0397$ & 0.00577 & 47.28 & $<0.0001$ \\
\hline & ${\text { Cubic } P_{3}}-0.00054$ & 0.000075 & 52.05 & $<0.0001$ \\
\hline \multirow{4}{*}{ 䏤 } & Intercept $P_{0}$ & 0.8295 & 34.90 & $<0.0001$ \\
\hline & Linear $\mathrm{P}_{1}$ & 0.1199 & 21.31 & $<0.0001$ \\
\hline & Quadratic $P_{2} \quad 0.0230$ & 0.00538 & 18.35 & $<0.0001$ \\
\hline & Cubic $P_{3}$ & 0.000075 & 23.16 & $<0.0001$ \\
\hline
\end{tabular}

A significant negative estimate for the parameter $P_{1}$ indicate that the slope of the functional response curve is declining,

thus a type II finctional response

Whereas, the type of functional response can be determined based on the sign of the linear coefficient: negative for type II, positive for type III (Juliano, 1993). Type II functional response is the most common functional response of the phytoseiid species to an increasing density of spider mites (Fernando and Hassell, 1980; Sabelis, 1985; Shipp and Whitfield, 1991 and Skirvin and Fenlon, 2003). Chant (1961) reported a Type II curve for P. persimilis on T. urticae. Laing and Osborn, 1974; Ryoo 1996 and Landeros et al., 2001 also, reported a functional Type II response curve for $P$. persimilis feeding on $T$. urticue adults.

The functional response data of $P$, persimilis on larvae, nymphs and adult fimales of $T$. urticae were successfully fitted to the Royma $\left(14^{-} \mid\right)$and Rogers (1972) equation (Fig. 2. Tahie - . The attack rate of
$P$. persimilis increased from 0.17 on larvae to 0.50 on nymphs but declines on adult female of T. urticae to 0.47 . Whereas, handling time $\left(T_{h}\right)$ of P. persimilis was $1.4699,2.1133$ and 3.051 when offering larvae, nymphs and adults of $T$. urticae, respectively. The expected maximum consumption $\left(\mathrm{T} / \mathrm{T}_{\mathrm{h}}\right)$ of $P$. persimilis was 16.32 larvae, 11.36 nymphs and 7.90 adults per day of $T$. urticae.

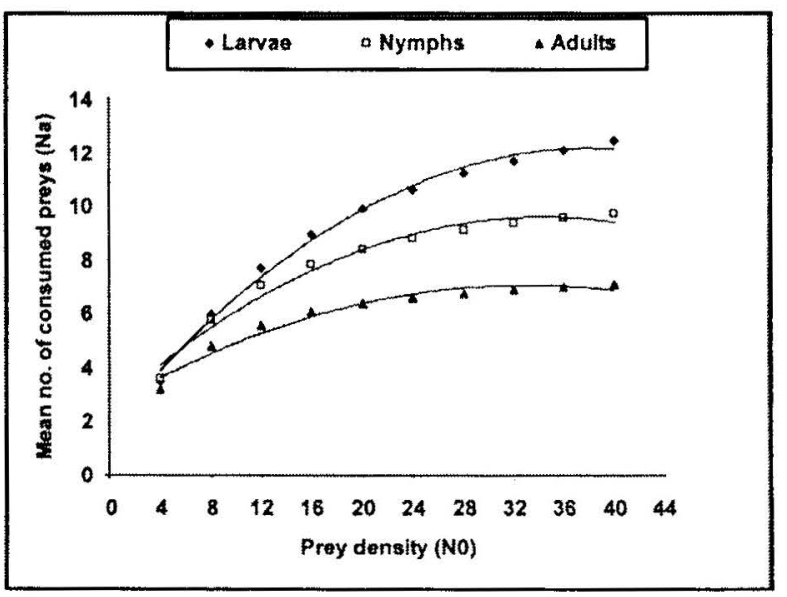

Fig. (2): Functional responses of Phytoseiulus persimilis on adults, nymphs and larvae of Tetranychus urticae at $25 \pm 1{ }^{\circ} \mathrm{C}$, the fitted lines are predictions of the Rogers (1972) model.

The level of functional responses is affected by the life stages of prey supplied. For example, Fernando and Hassell (1980) showed that the maximum number of $T$. urticke consumed by $P$. persimilis decreased in the order: egg, larva, protonymph and deutonymph. Still further, phytoseiid mites very seldom prefer to feed on adult mites but most often they feed on immature stages (Sabelis, 1985). Blackwood et al. (2001) reported that adult females of $P$. persimilis preferred $T$. urticae eggs over the larvae. In contrast, Popov and Kondryakov (2008) reported that adult females of $P$. persimilis consumed more males of Tetranychus 
Table (2): Effect of Tetranychus urticae stage on the attack rate (a), handling time $\mathrm{T}_{\mathrm{h}}$ and maximum number of consumption $\left(\mathrm{T} / \mathrm{T}_{\mathrm{h}}\right.$ ) on $P$. persimilis derived from random predator equation.

\begin{tabular}{|c|c|c|c|c|c|c|c|}
\hline \multirow[b]{2}{*}{ Stages } & \multirow{2}{*}{$A$} & \multicolumn{2}{|c|}{ Asymptotic $95 \% \mathrm{CI}$} & \multirow[b]{2}{*}{$\mathrm{T}_{\mathrm{h}}$} & \multicolumn{2}{|c|}{ Asymptotic $95 \% \mathrm{CI}$} & \multirow[b]{2}{*}{$\mathrm{T} / \mathrm{T}_{\mathrm{h}}$} \\
\hline & & lower & upper & & lower & upper & \\
\hline Larva & $0.17 \pm 0.04$ & 0.07 & 0.26 & $1.46 \pm 0.09$ & 1.28 & 1.65 & 16.32 \\
\hline Nymph & $0.50 \pm 0.48$ & 0.25 & 1.46 & $2.11 \pm 0.13$ & 1.83 & 2.38 & 11.36 \\
\hline Adult & $0.47 \pm 0.71$ & 0.11 & 1.90 & $3.03 \pm 0.26$ & 2.50 & 3.56 & 7.90 \\
\hline
\end{tabular}

spp. than the eggs or females. These contrasting results may be related to differences in experimental design and number of prey provided. Fernando and Hassell (1980) reported that the search rate and the handling time of females of $P$. persimilis preying on eggs of $T$. urticae were 1.69 and 0.87 (h), respectively. It should be realized that predation by phytoseiid mites is generally not limited by handling time but by digestion rate (e.g. Sabelis, 1985).

The results showed that $P$. persimilis females were more effective at low different prey stages densities. Also, increase predation rate and short handling time of $P$. persimilis females as function of $T$. urticae larvae, guide us to release $P$. persimilis early on low prey densities and the best time when the prey is in larval stage.

\section{REFERENCES}

El-Laithy, A. Y. M. 1992. Some aspects on the use of the predaceous mite Phytoseiulus persimilis Athias - Henriot. For biological control of the two spotted spider mite Tetranychus urticae koch in greenhouses in Egypt. J. Plant Dis.,Prot. 99: 93-100.

El-saiedy, S. M., 1999. Integrated control studies on Tetranychus urticae koch on soya bean plant. M. Sc. Thesis, Fac. Of Agric. Minufiya Univ.

El-saiedy, S. M., 2003. Integrated control studies on red spider mite Tetranychus urticae koch on strawberry plants. Ph. D. Thesis, Fac. of Agric. Cairo Univ.

Badii, M.H.; McMurtry, J.A. and Flores, A. E., 1999. Rates of development, survival and predation of immature stages of Phytoseiulus longipes (Acari: Mesostigmata: Phytoseiidae). Exp. Appl. Acarol., 23:611-621.

Blackwood, J.S. ; Schausberger, P. and Croft, B.A., 2001. Prey stage preferences in generalist and specialist phytoseiid mites (Acari: Phytoseiidae) when offered Tetranychus urticae (Acari: Tetranychidae) eggs and larvae. Enviro. Entom., 30, 1103-1111.

Chant, D.A. 1961. The effect of prey density on prey consumption and oviposition in adults of
Typhlodromus occidentalis (Nesbitt) in the laboratory. Can. J. Zool., 39:311-315.

Cuellar, M.E.; Calatayud, P.; Melo, E.L.; Smith, L. and Bellotti, A.C. 2001. Consumption and oviposition rates of six phytoseiid species feeding on eggs of the cassava green mite Mononychellus tanajoa (Acari: tetranychidae). Fla. Entomol.. 84:602-607.

Everson, P. 1979. The functional response of Phytoseiulus persimilis (Acarina: Phytoseiidae) to various densities of Tetranychus urticae (Acarina:Tetranychidae).Can Entomol., 111:7-10

Everson, P. 1980. The relative activity and functional response of Phytoseiulus persimilis (Acarina: Phytoseiidae) and Tetranychus urticae (Acarina: Tetranychidae): the effect of temperature. Can. Entomol., 112:17-24.

Fernando, M. and Hassell, M. 1980. Predator-pres responses in an acarine system. Res. Popul. Ecol. 22: 301-322.

Fernández-Arhex, V. and Corley, J. C. 2003. The functional response of parasitoids and its implications for biological control. Biocontrol Science and Technology, 13: 403-413.

Hassell, M.P., 1978. The Dynamics of Arthropod Predator Prey Systems Monographs in Population Biology 13, pp: 1-237 Princeton, N.J: Prinnceton University Press.

Holling, C. S. 1959a. The components of predation as revealed by a study of small-mammal predation of the European pine sawfly. Can. Entomol., $91: 293-320$.

Holling, C. S. 1959b. Some characteristics of simple types of predation and parasitism. Can. Entomol.. 91:385-398.

Holling, C. S. 1961. Principles of insect predation. Annl. Rev. Entomol., 6: 163-183.

Hughes, R. D.; Woolcok, L.T. and Hughes, M. A. 1992. Laboratory evaluation of the parasitic Hymenoptera used in attempts to biologically control aphid pests of crops in Australia. Entomologia Experimentalis et Applicata. 63: 177-185.

Jackson, G. J. and Ford, J. B. 1973. The feeding behaviour of Phytoseiulus persimilis (Acarina: Phytoseiidae), particularly as affected by certain 
pesticides. Ann. Appl. Biol., 75:165-171.

Juliano, S. A., 1993. Nonlinear curve fitting: predation and functional response curves. In: Design and Analysis of Ecological Experiments. Ed. by SCHEINER, S. M.; GUREV- ITCH, J. New York: Chapman \& Hall, 159-182.

Juliano, S. A., 2001. Nonlinear curve-fitting: predation and functional response curves. In: Scheiner SM, Gurevitch $\mathrm{J}$ (eds) Design and analysis of ecological experiments, 2nd edn. Oxford University Press, New York, pp 178-196

Landeros, J.; Rodriguez, S.; Badii, M.H.; Cerda, P.A. and Flores, A. E., 2001. Functional response and population parameters of Phytoseiulus persimilis Athias-Henriot on Tetranychus urticae Koch. Southwest Entomologist, 26:253-257.

Laing, J. E. and Osborn, J.A., 1974. The effect of prey density on the functional and numerical responses of three species of predatory mites. Entomophaga, 19:267-277.

Luck, R.F., 1984. Principles of arthropod predation. Ecological Entomology (eds. C.B. Huffaker \& R.L. Rabb), pp. 497 - 530. Wiley Interscience, New York.

Mandour, N.S.; El-Basha, N.A. and Liu, T.X., 2006. Functional response of the ladybird, Cydonia vicina nilotica to cowpea aphid, Aphis craccivora in the laboratory. Insect Sci., 13: 49-54

Oaten, A. and Murdoch, W.W., 1975. Functional response and stability in predator-prey systems. American Nat., 109: 289-298

Overmeer, W. P. J., 1985. Rearing and handling. In: Helle, W., Sabelis, M.W. (Eds.), Spider Mites: Their biology, natural enemies and control. World Crop Pests. Elsevier.

Pervez, A. and Omkar, J. BE., 2005. Functional responses of coccinellid predators: an illustration of a logistic approach. Journal of Insect Science, 5: 1-6.

Popov, S.Y.and Kondryakov, A.V., 2008. Reproductive tables of predatory phytoseiid mites (Phytoseiulus persimilis, Galendromus occidentalis and Neoseiulus cucumeris). Entomological Review, 88: 658-665.

Rasmy, A. H. and El-Laithy, A. Y. M., 1988. Introduction of Phytoseiulus persimilis for the two spotted spider mite control in greenhouses in Egypt. (Acari: Phytoseiidae, Tetranychidae). Entomophaga, 33: 435- 438.

Ryoo, M. I., 1996. Influence of the spatial distribution pattern of prey among patches and spatial coincidence on the functional and numerical response of Phytoseiulus persimilis (Acarina: Phytoseiidae). J. Appl. Entomol. 120:187-192.

Royama, T. 1971. A comparative study of models for predation and parasitism. Res. Popul. Ecol., 1: 1-91.

Sabelis, M.W., 1981. Biological control of twospotted spider mites using phytoseiid predators. Part I: modelling the predator-prey interaction at the individual level. Agricultural Research Reports, Pudoc, Wageningen, p. 242

Sabelis, M. W., 1985. Predator-prey interaction: predation on spider mite. In: Helle W, Sabelis MW (eds) World crop pests 1B. spider mites: their biology natural enemies and control. Elsevier, Amsterdam,: 103-129

Santos, M. A. 1975. Functional and numerical responses of the predatory mite, Amblyseius fallacis, to prey density. Environ. Entomol., 4:989-992

Shipp, J. and Whitfield, G., 1991. Functional response of the predatory mite, Amblyseius cucumeris (Acari: Phytoseiidae), on western flower thrips, Frankliniella occidentalis (Thysanoptera: Thripidae). Environ. Entomol., 20: 694-699.

Skirvin, D. J. and Fenlon, J.S., 2003. The effect of temperature on the functional response of Phytoseiulus persimilis (Acari: Phytoseiidae). Exp. Appl. Acarol., 31, 37-49.

Solomon, M. E. 1949. The natural control of animal populations. J. Anim. Ecol., 18:1-35.

Tully, T.; Cassey, P. and Ferriere, R., 2005. Functional response: rigorous estimation and sensitivity to genetic variation in prey. Oikos, 111:479-487.

Van Rijn P. C. J., Bakker F. M., Van der Hoeven W. A. D., Sabelis M. W., 2005. Is arthropod predation exclusively satiation-driven? Oikos, 109:101-116. 